\title{
PEMODELAN HARGA CPO INDONESIA TAHUN 2018 DENGAN ARIMA
}

\author{
ARIMA Modelling for Indonesian 2018 CPO Price
}

\author{
Devi Oktiani \\ Balai Riset dan Standardisasi Industri Bandar Lampung, Jl. By Pass Soekarno Hatta KM.1 Rajabasa \\ Bandar Lampung, 35412. Indonesia \\ e-mail : divya_de_vi@yahoo.com
}

\begin{abstract}
ABSTRAK: Pada tahun 2018 ini harga CPO di Indonesia cenderung menurun. Tulisan ini bertujuan menggambarkan model harga CPO pada tahun 2018 dan peramalanya untuk 120 hari ke depan. Data yang digunakan adalah data harga CPO per hari dari bulan Januari hingga bulan November tahun 2018. Berdasar karakteristik data maka dapat digunakan model Autoregressive Integrated Moving Average (ARIMA). Didapatkan Model ARIMA yang sesuai adalah ARIMA $(4,1,3)$ dengan mean square of errors $M S=20,74$. Dilakukan uji validitas model dan dilakukan peramalan harga CPO untuk 120 hari, peramalan menunjukkan harga CPO cenderung menurun.
\end{abstract}

Kata kunci: ARIMA, CPO, Indonesia, peramalan, harga, 2018.

\begin{abstract}
In this year, 2018 the price of CPO in Indonesia is tend to decrease. The objective of this paper is to describe the model for 2018 CPO price and to forecast the price for the following 120 days. The data are daily CPO prices from January to November 2018. Based on data characteristics, the Autoregressive Integrated Moving Average (ARIMA) model can be applied. The fit ARIMA model is ARIMA $(4,1,3)$ with the mean square of errors $M S=20,74$. The validity of the model is tested and the forecast for the following 120 days describes that $C P O$ price is tend te decrease.
\end{abstract}

Keywords: ARIMA, CPO, forecast, Indonesia, price, 2018

\section{PENDAHULUAN}

\subsection{Kondisi Perdagangan CPO Tahun 2018}

Kelapa sawit merupakan salah satu komoditas ekspor utama Indonesia. Negara penghasil dan pengekspor $\mathrm{CPO}$ terbesar adalah Indonesia diikuti oleh Malaysia (Bentivoglio, 2018). Indonesia memiliki keunggulan komparatif terhadap negara -negara lain dalam hal ekspor $\mathrm{CPO}$, keunggulan komparatif ini cenderung untuk selalu positif (Alatas, 2015). Pada tahun 2017 peran sawit dalam ekspor produk non migas sebesar 12,13\% (Kemendag, 2018). Namun demikian, nilai ekspor sawit Indonesia dari tahun 2014 ke tahun 2016 cenderung mengalami penurunan, dari 17.464.904,700 US\$ pada tahun 2014 turun menjadi 15.385.275,300 US\$ pada tahun 2015 dan 14.366.754.000 US\$ pada tahun 2016, lebih rinci pada Tabel 1. Penurunan nilai ekspor sawit antara lain disebabkan oleh penurunan harga $\mathrm{CPO}$ di pasar global. Harga CPO di pasar internasional secara umum menurun karena perlambatan pertumbuhan ekonomi secara global.
Kebijakan pemerintah negara India untuk menaikkan bea masuk produk CPO asal Indonesia turut mempengaruhi penurunan ekspor CPO. India adalah Negara tujuan ekspor CPO Indonesia yang terbesar. India juga merupakan negara yang mengkonsumsi CPO paling besar di dunia (Nurcahyani, 2018). Pemerintah India menetapkan bea masuk impor CPO $44 \%$ dan minyak goreng sawit 54\% sejak 1 Maret 2018. Penurunan nilai ekspor sawit terlihat pada nilai ekspor pada bulan Januari hingga Juni 2017 adalah 2,5216 juta US\$ dan menuruan pada Januari hingga Juni 2018 adalah 1,4909 juta US\$. Pemerintah India bermaksud untuk meningkatkan produktifitas perkebunan sawit dan tanaman penghasil minyak makan di India, misalnya jagung dan kedelai untuk mengurangi ketergantungan CPO dari Negara lain. Terdapat penelitian terdahulu yang menyatakan bahwa ada hubungan antara pajak ekspor CPO Indonesia ke India (Munadi,E., 2007).

Ekspor ke negara - negar Eropa juga mengalami penurunan yang disebabkan oleh prespektif negatif masyarakat Eropa terhadap $\mathrm{CPO}$, misalnya tentang adanya kandungan 
3MCPD pada minyak goreng sawit yang dapat mempengaruhi kesehatan. Bea masuk CPO ke Eropa juga mengalami kenaikan.

Secara teori, penurunan ekspor dapat menyebabkan melimpahnya pasokan sawit Indonesia dan berdampak pada penurunan harga CPO Indonesia. Dampak yang dapat ditimbulkan secara jangka panjang adalah penurunan penyerapan tenaga kerja di sektor perkebunan sawit dan secara umum mempengaruhi pertumbuhan ekonomi Indonesia, karena sawit adalah salah satu komoditas utama di Indonesia. Meskipun demikian, terdapat penelitian terdahulu yang menyatakan bahwa harga CPO mempengaruhi pasokan secara signifikan, tetapi jumlah pasokan tidak mempengaruhi harga secara signifikan (Rambe, 2018).

Latar Belakang penulisan penelitian ini, adalah untuk menunjukkan seberapa jauh kemungkinan penurunan harga CPO, sehingga diharapkan pihak yang berkepentingan dapat mengambil langkah strategis untuk mengantisipasi dampak yang ditimbulkan.

Pada penelitian ini, harga CPO akan disimulasikan terhadap variable harga CPO itu sendiri, sehingga akan digunakan model ARIMA. Meskipun demikian harga CPO ini juga dapat dipengaruhi oleh harga minyak makan yang lain. Terdapat penelitian terdahulu yang menyebutkan bahwa pasokan minyak kedelai secara internasional mempengaruhi pasokan $\mathrm{CPO}$ dan pada akhirnya mempengaruhi harga $\mathrm{CPO}$ (Bentivoglio, et.al., 2018; Buyung,et.al., 2017).

Pada tulisan ini, dianalisis model yang sesuai untuk menggambarkan kondisi harga CPO Indonesia pada tahun 2018 dan dilakukan peramalan (forecast) harga CPO untuk 120 hari ke depan. Model yang digunakan dipilih berdasar karakteristik data dan variabel.

\subsection{Model ARIMA}

Data yang digunakan dalam tulisan ini adalah data time series perhari, dan diduga bahwa bahwa data hari ke $t$ dapat mempengaruhi harga pada hari ke $t+1$ hingga $t+n$. Variabel yang digunakan adalah harga itu sendiri. Dari karakteristik data pada gambar 1 dan jenis variabel yang digunakan maka dapat diduga bahwa model yang sesuai digunakan adalah model autoregressive integrated moving average (ARIMA), merupakan gabungan antara model autoregression dan moving average. Dalam hal ini maksud kata 'integrated' adalah kebalikan dari defernsiasi.

Terdapat penelitian terdahulu yang membandingkan beberapa model dan menyimpulkan bahwa salah satu model yang dapat digunakan untuk memprediksi model harga CPO adalah ARIMA (Rahim, NF, 2018). Namun demikian karakteristik data setiap waktu adalah berbeda beda, sehingga kesimpulan tersebut berlaku secara umum.

Menurut Hyndman dan Athanasopoulus (2018), model autoregressive order ke- $p$ dapat dituliskan sebagai berikut,

$\mathrm{y}_{\mathrm{t}}=\mathrm{c}+\phi_{1} \mathrm{y}_{\mathrm{t}-1}+\phi_{2} \mathrm{y}_{\mathrm{t}-2}+\ldots \ldots .+\phi_{\mathrm{p}} \mathrm{y}_{\mathrm{t}-\mathrm{p}}+\varepsilon_{\mathrm{t}} \ldots \ldots$

Keterangan :

$\mathrm{y}_{\mathrm{t}}=$ nilai variable $\mathrm{y}$ pada tahun ke-t.

$\phi=$ koefisien

$\mathrm{c}=$ konstanta

$\varepsilon_{\mathrm{t}}=$ white noise atau residu.

Model Moving Average pada order ke- $q$ adalah sebagai berikut,

$\mathrm{y}_{\mathrm{t}}=\mathrm{c}+\varepsilon_{\mathrm{t}}+\Theta_{1} \varepsilon_{\mathrm{t}-1}+\Theta_{2} \varepsilon_{\mathrm{t}-2}+\ldots .+\Theta_{\mathrm{q}} \varepsilon_{\mathrm{t}-\mathrm{q}} \ldots \ldots$.

Keterangan:

$\mathrm{y}_{\mathrm{t}}=$ nilai variable $\mathrm{y}$ pada tahun ke-t.

$\Theta=$ koefisien

$\mathrm{c}=$ konstanta

$\mathcal{E}_{\mathrm{t}}=$ white noise pada tahun ke-t, atau residu.

Regresi dilakukan pada deret yang stasioner, jika belum stasioner maka harus dilakukan diferensiasi,

$y^{\prime}{ }_{t}=y_{t}-y_{t-1}$

Keterangan :

$\mathrm{y}_{\mathrm{t}}=$ diferensasi pertama atau selisih atau $1^{\text {st }}$ difference y pada tahun ke-t .

Gabungan antara moving average dan autoregressive untuk deret terdiferensiasi $l^{s t}$ difference secara lengkap model dapat dituliskan sebagai berikut (Hyndman dan Athanasopoulus ,2018),

$\mathrm{y}^{\prime}{ }_{\mathrm{t}}=\mathrm{c}+\phi_{1} \mathrm{y}_{\mathrm{t}-1}+\ldots+\phi_{\mathrm{p}} \mathrm{y}_{\mathrm{t}-\mathrm{p}}{ }^{\prime}+\Theta_{1 \varepsilon \mathrm{t}-1}+\ldots+\Theta_{\mathrm{q} \varepsilon \mathrm{t}-1}+\varepsilon_{\mathrm{t}} .$.

Keterangan:

$\mathrm{y}_{\mathrm{t}}{ }_{\mathrm{t}}=$ deret yang terdiferensiasi,

dapat terdiferensiasi lebih dari satu kali.

$\phi=$ koefisien

$\Theta=$ koefisien

Model dituliskan sebagai ARIMA (p,d,q), dengan

$\mathrm{p}=$ order autoregressive

$\mathrm{d}=$ tingkat differensiasi

$\mathrm{q}=$ order moving average .

Berdasar prosedur Box-Jenkins, model dan peramalan ini terdiri dari beberapa tahapan, meliputi identifikasi, estimasi model, evaluasi model, dan peramalan (Firdaus, M., 2011).

Salah satu syarat melakukan regresi dengan model ini adalah bahwa regresi dilakukan pada 
deret data yang stasioner. Salah satu cara untuk mengeksplorasi pola data adalah dengan melihat autocorrelation. Autocorrelation adalah korelasi antara nilai peubah $(\mathrm{y})$ dengan nilai lag nya $\left(\mathrm{y}_{\mathrm{t}-1}\right)$, baik untuk waktu satu kurun atau kurun waktu selebihnya. Kumpulan AC untuk berbagai lag disebut autocorrelation function (ACF) (Firdaus,M., 2011).

Tahap awal pemodelan adalah identifikasi, yaitu identifikasi terhadap 3 hal yaitu pola data, dan terdapat kecenderungan musiman atau tidak. Kemudian uji kestasioneran data, dan selanjutnya adalah identifikasi terhadap perilaku ACF dan parsial ACF (PACF) (Firdaus,M., 2011).

Tahap selanjutnya adalah estimasi model, estimasi model dilakukan dengan cara melihat bentuk grafik ACF dan PACF. Dan selanjutnya digunakan program computer untuk mengestimasi koefisien masing -masing parameter (Firdaus,M., 2011).

Tahap evaluasi dilakukan untuk memperoleh model tentatif, dilakukan uji kedekatan model dengan data. Pengujian dilakukan dengan menguji nilai residual variabel dan dengan menguji signifikansi dan hubungan hubungan antara parameter. Jika ada hasil uji yang tidak dapat diterima atau tidak memenuhi syarat, maka model harus diperbaiki dan langkah sebelumnya diulang kembali (Firdaus,M., 2011).

Tahap peramalan dapat dilakukan setelah evaluasi model. Dalam model ARIMA proses peramalan bersifat linier dan seleksi model didasarkan pada prinsip parsimony, artinya model yang dipilih adalah model dengan parameter yang sesedikit mungkin.

\section{METODE}

\subsection{Data}

Data berupa harga CPO per hari didapatkan dari website GAPKI Indonesian Palm Oil Association, https://gapki.id/,_data tersedia hanya pada hari kerja, sehingga dilakukan interpolasi data untuk harga CPO pada tanggal -tanggal yang tidak tersedia datanya. Dari 1 Januari 2018 hingga 28 November 2018 didapatkan 329 data.

Tulisan ini dibuat pada Desember 2018, sehingga data Desember belum dapat disertakan.

\subsection{Alat}

Perhitungan dan analisis data menggunakan software Minitab 16.

\subsection{Metoda}

Secara umum metoda yang digunakan adalah metoda kuantitatif berupa regresi, dengan rincian sebagai berikut,

\subsubsection{Identifikasi}

Dilakukan identifikasi terhadap pola data (gambar 1), dan dapat diduga bahwa model yang digunakan dapat berupa ARIMA model. Gambar 1 menunjukkan bahwa terdapat trend (kecenderungan) terhadap data, data tidak stasioner, sehingga dapat dikatakan bahwa regresi tidak dapat dilakukan pada level, tetapi harus dilakukan pada diferensiasi. Dalam hal ini juga dilakukan identifikasi terhadap karakteristik ACF dan PACF yang ditampilkan dalam korelogram. Identifikasi harus dapat menentukan pada level yang mana data tersebut stasioner sehingga dapat dilakukan regresi.

\subsubsection{Estimasi Model}

Estimasi model ARIMA(p,d,q) dapat dimulai dengan melihat bentuk korelogram ACF dan PACF. Estimasi model ini merupakan penetuan nilai p, d, dan q. Korelogram ACF yang berbentuk pola menurun mendekati 0 secara landai (dying down) merepresentasikan bahwa terdapat trend (kecenderungan) dalam data, tidak stasioner. Sedangkan korelogram yang berbentuk menurun secara tiba-tiba (cut off) merepresentasikan bahwa data stasioner. Titik ke berapa korelogram cut off mengindikasikan order $\mathrm{p}$ dan q. Korelogram PACF mengindikasikan order $\mathrm{p}$, sedangkan korelogram ACF mengindikasikan order q.

\subsubsection{Uji Diagnostik untuk Evaluasi Model}

Setelah dilakukan evaluasi model, maka selanjutnya perlu dipastikan apakah model yang diestimasi sudah baik atau belum. Terdapat enam kriteria dalam evaluasi model, yaitu :

a. Residual error bersifat random. Indikator yang digunakan adalah nilai pvalue untuk uji statistik lebih besar dari 0,05. Selain itu grafik ACF dan PACF dari residu menunjukkan pola cut off yang berarti sudah random.

b. Model prosimonious.

Model harus yang paling sederhana. Nilai p,d, dan q sebaiknya dipilih yang kecil yang memungkinkan.

c. Parameter yang direstimasi berbeda nyata dengan nol. 
Hal ini ditunjukkan dengan p-value masing-masing koefisien yang kurang dari 0,05 .

d. Kondisi invertibilitas ataupun stasioneritas terpenuhi.

Hal ini ditunjukkan dengan jumlah koefisien MA dan AR yang masing masing harus kurang dari 1.

e. Proses iterasi convergence.

Hal ini ditunjukkan pada saat analisis dijalankan akan terdapat kata-kata "relative change in each estimate less than 0,0010 ".

f. Model memiliki MSE yang kecil .

Hal ini dapat dilihat pada nilai MS yang ditunjukkan saat analisis dijalankan.

Jika model yang dipilih belum valid, maka harus dilakukan perubahan $\mathrm{p}$ atau $\mathrm{q}$ sehingga model valid. Perubahan $\mathrm{p}$ dan $\mathrm{q}$ dilakukan secara bertahap, dan dilakukan uji validitas hingga didapatkan model yang valid. Perubahan $\mathrm{p}$ dan $\mathrm{q}$ dapat dilakukan berkali-kali, dan dapat dibandingkan model yang terbaik berdasar uji validitasnya.

\subsubsection{Peramalan (forecast)}

Peramalan dapat dilakukan setelah model yang didapatkan valid. Dalam tulisan ini dilakukan peramalan harga CPO selam 120 hari setelah hari data terakhir. Terdapat data hari ke 1 hingga 329, maka yang diramalan adalah harga CPO mulai hari ke-330. Pada peramalan ini didapatkan nilai peramalan, batas bawah, dan batas akhir dengan tingkat kepercayaan $95 \%$.

\section{HASIL DAN PEMBAHASAN}

3.1. Ekspor CPO Indonesia

Tabel 1 menggambarkan nilai ekspor sawit Indonesia dari tahun ke tahun. Negara tujuan ekspor utama sawit Indonesia adalah India.

Tabel 1 Nilai Ekspor Sawit Indonesia

\begin{tabular}{ll}
\hline \multicolumn{1}{c}{ Tahun } & $\begin{array}{c}\text { Nilai Ekspor } \\
\text { FOB (ribu US\$) }\end{array}$ \\
\hline 2012 & $17.602 .168,0$ \\
2013 & $15.838 .850,2$ \\
2014 & $17.464 .904,7$ \\
2015 & $15.385 .275,3$ \\
2016 & $14.366 .754,0$ \\
2017 & $16.947 .989,7$ \\
\hline
\end{tabular}

Sumber Data:

http://www.kemendag.go.id/id/economic-profile/10main-and-potential-commoditiesBadan Pusat Statistik, 2013, 2014, dan 2015
Tabel 2 Ekspor Sawit ke Negara Tujuan Ekspor Sawit Indonesia (Juta US\$)

\begin{tabular}{lcc}
\hline \multicolumn{1}{c}{ Negara } & $\begin{array}{c}\text { Januari- } \\
\text { Juni 2017 }\end{array}$ & $\begin{array}{c}\text { Januari- } \\
\text { Juni 2018 }\end{array}$ \\
\hline India & 2521,6 & 1490,9 \\
RRC & 802,1 & 948,1 \\
Pakistan & 717,7 & 686,4 \\
Spanyol & 504,5 & 402,9 \\
Bangladesh & 394,4 & 479,6 \\
Mesir & 430,8 & 291,9 \\
Belanda & 426,8 & 316,4 \\
Italia & 362,2 & 311,4 \\
USA & 274,7 & 297,3 \\
Malaysia & 311,2 & 222,7 \\
\hline
\end{tabular}

Sumber Data :

http://www.kemendag.go.id/id/economic-profile/10main-and-potential-commodities/10-maincommodities

Kebijakan pemerintah India untuk meningkatkan bea masuk CPO ke India dan meningkatkan produktifitas perkebunan dan industri minyak makan di negaranya jelas telah berpengaruh terhadap perdagangan internasional CPO Indonesia. Penurunan nilai ekspor CPO ke India sangat mempengaruhi keseluruhan ekspor $\mathrm{CPO}$ Indonesia. Peningkatan ekspor $\mathrm{CPO}$ ke beberapa negara, misalnya ke China, Pakistan, Bangladesh, dan USA tidak terlalu besar disbanding dengan penurunan nilai ekspor CPO. Hal ini menyebabkan pasokan CPO berlimpah, dan harga CPO secara keselutuhan mernurun.

Harga CPO per hari di Indonesia dari tanggal 1 Januari 2018 hingga 28 November 2018 cenderung mengalami penurunan. Harga CPO yang semula berkisar pada 650 US\$ dapat turun hingga 450 US\$. Harga CPO ini dipengaruhi oleh harga CPO internasional dan data harga CPO pada tulisan ini adalah harga untuk perdagangan internasional CPO Indonesia. Gambar 1 menunjukkan bahwa harga CPO per hari berfluktuasi dengan kecenderungan stasioner di awal dan kemudian menurun sejak hari ke 160 .

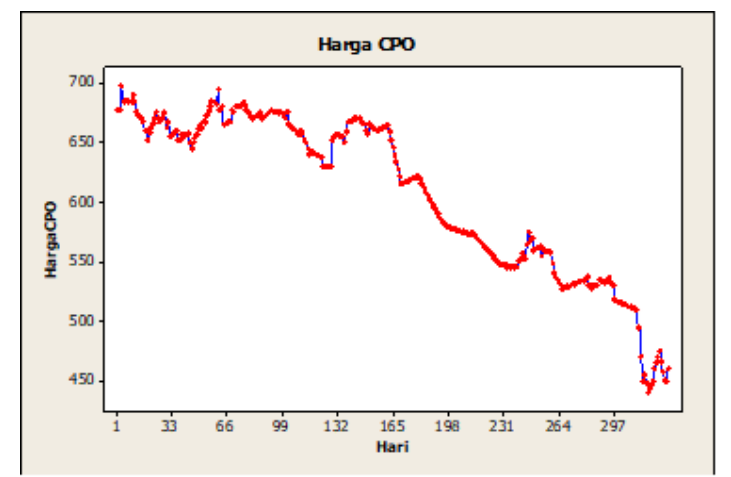

Gambar 1. Harga CPO Indonesia Tahun 2018 (US\$) Sumber : https://gapki.id/, diolah. 


\subsection{Model ARIMA}

Telah dilakukan analisis nilai ACF dan PACF haga CPO pada level tanpa diferensiasi, gambar 2 menunjukkan bahwa ACF berbentuk dying down atau menurun perlahan, yang berarti data tidak stasioner pada level. Stasioner atau tidak stationernya data ditunjukkan dari bentuk ACF. Salah satu syarat dalam melakukan regresi ARIMA adalah bahwa data harus pada level yang stasioner, Regresi ini tidak dapat dilakukan pada level harga CPO sehingga dilanjutkan dilakukan analisis kemungkinan untuk melakukan regresi pada level $1^{\text {st }}$ difference atau turunan pertama harga CPO. Gambar PACF harga CPO (gambar 3) menunjukkan bahwa PACF cut off, atau tiba tiba turun setelah data pertama, hal ini mengindikasikan bahwa regresi dapat dilakukan pada turunan pertama ( $I^{\text {st }}$ difference $)$.

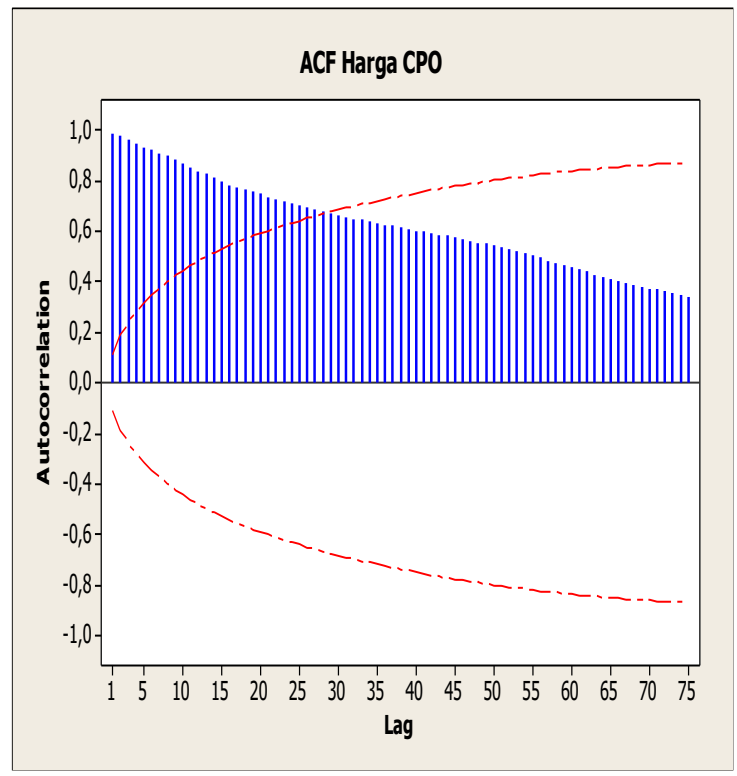

Gambar 2. ACF Harga CPO Indonesia Tahun 2018

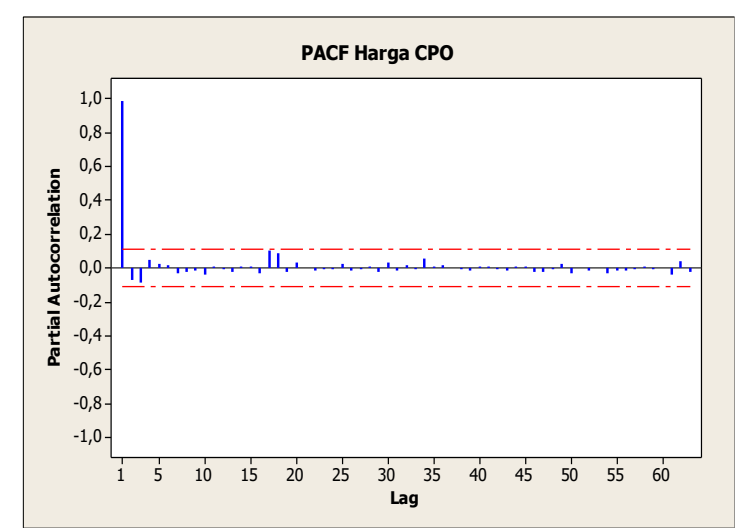

Gambar 3. PACF Harga CPO Indonesia Tahun 2018
Analisis nilai ACF dan PACF pada $1^{s t}$ difference menggambarkan bahwa data telah stasioner pada diferensiasi pertama, Gambar ACF $I^{\text {st }}$ difference (Gambar 4) menunjukkan bahwa ACF bersifat acak, tidak menunjukkan kecenderungan bentuk tertentu, tidak cenderung meningkat atau menurun, sehingga dapat dilakukan regresi pada $I^{\text {st }}$ difference. $\operatorname{ARIMA}(\mathrm{p}, \mathrm{d}, \mathrm{q})$, dapat ditentukan bahwa d adalah 1 karena turunan pertama. Gambar 3 dan 4 menunjukkan bahwa korelogram bersifat cut off atau menurun secara tiba -tiba pada titik tertentu, yaitu setelah titik ke-3. Maka dilakukan dugaan awal bahwa orde $\mathrm{p}$ dan $\mathrm{q}$ adalah 3 .

Setelah beberapa kali uji validitas, didapatkan bahwa model ARIMA yang sesuai adalah ARIMA $(4,1,3)$. Diadapatkan hasil regresi Tabel 3 dan Tabel 4. Pada proses uji validitas model ini, dilakukan perhitungan Sum of Square of Errors untuk 23 tahap iterasi, dari tahap iterasi tersebut dianalisis perbedaan estimasinya. Hasil Estimasi (Tabel 3) menunjukkan bahwa relative perubahannya tidak terlalu besar, kurang dari 0,0010 , sehingga model dapat diterima.

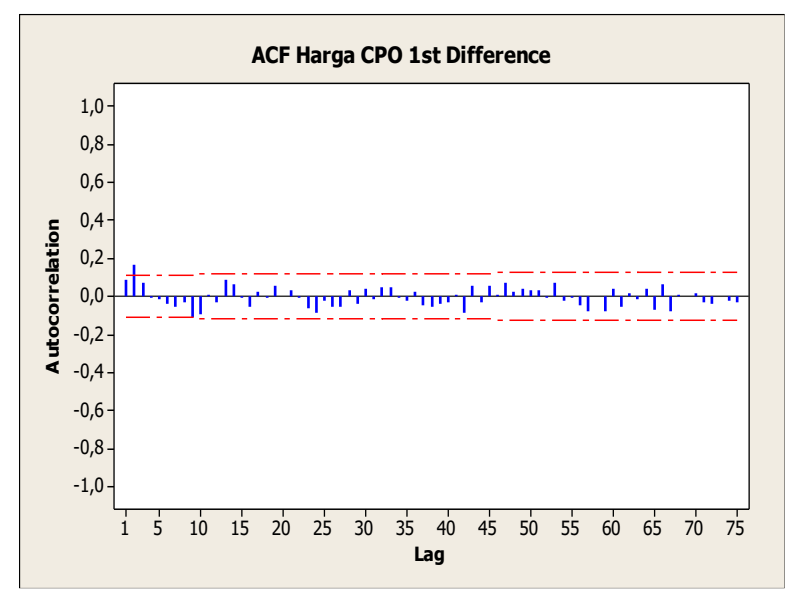

Gambar 4. ACF $1^{\text {st }}$ Difference

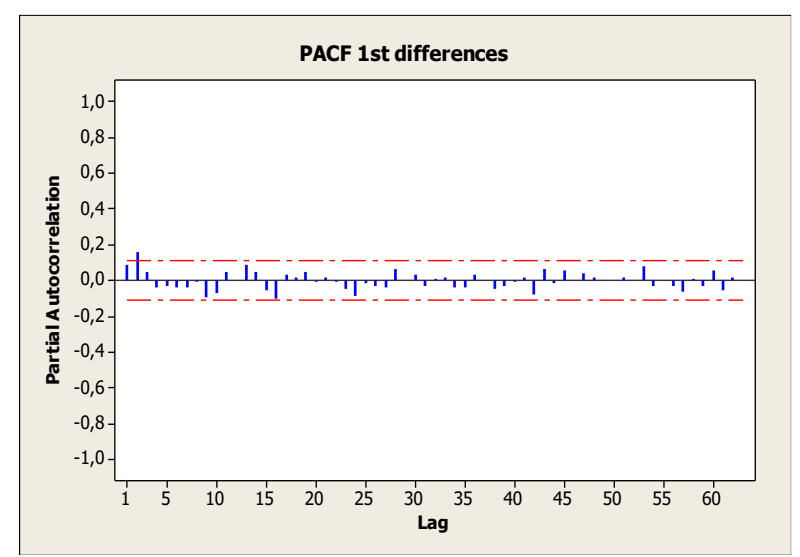

Gambar 5. PACF $1^{\text {st }}$ Difference 
Tabel 3. Nilai Sum of Square of Errors (SSE) dan Koefisian Tiap Parameter AR danMR

\begin{tabular}{|c|c|c|c|c|c|c|c|c|c|}
\hline Iterasi & SSE & AR 1 & AR2 & AR3 & AR4 & MR1 & MR2 & MR3 & c \\
\hline 0 & 7155,95 & 0,1 & 0,1 & 0,1 & 0,1 & 0,1 & 0,1 & 0,1 & $-0,338$ \\
\hline 1 & 6928,56 & $-0,026$ & 0,013 & $-0,002$ & 0,044 & $-0,05$ & $-0,046$ & $-0,013$ & $-0,585$ \\
\hline 2 & 6869,19 & 0,06 & $-0,116$ & $-0,137$ & 0,043 & 0,027 & $-0,196$ & $-0,158$ & $-0,702$ \\
\hline 3 & 6835,26 & 0,037 & $-0,246$ & $-0,081$ & 0,048 & $-0,003$ & $-0,346$ & $-0,118$ & $-0,767$ \\
\hline 4 & 6821,32 & 0,187 & $-0,329$ & $-0,08$ & 0,051 & 0,145 & $-0,43$ & $-0,11$ & $-0,725$ \\
\hline 5 & 6809,57 & 0,337 & $-0,442$ & $-0,056$ & 0,056 & 0,293 & $-0,542$ & $-0,077$ & $-0,686$ \\
\hline 6 & 6798,6 & 0,487 & $-0,556$ & $-0,023$ & 0,062 & 0,441 & $-0,653$ & $-0,034$ & $-0,641$ \\
\hline 7 & 6784,63 & 0,637 & $-0,692$ & 0,022 & 0,07 & 0,59 & $-0,787$ & 0,022 & $-0,601$ \\
\hline 8 & 6768,25 & 0,787 & $-0,815$ & 0,07 & 0,076 & 0,738 & $-0,908$ & 0,082 & $-0,552$ \\
\hline 9 & 6747,69 & 0,937 & $-0,939$ & 0,139 & 0,087 & 0,883 & $-1,042$ & 0,163 & $-0,491$ \\
\hline 10 & 6736,07 & 0,931 & $-0,849$ & 0,191 & 0,061 & 0,87 & $-0,974$ & 0,206 & $-0,424$ \\
\hline 11 & 6733,77 & 0,936 & $-0,899$ & 0,131 & 0,089 & 0,874 & $-1,024$ & 0,161 & $-0,473$ \\
\hline 12 & 6730,4 & 0,894 & $-0,84$ & 0,149 & 0,069 & 0,833 & $-0,971$ & 0,166 & $-0,462$ \\
\hline 13 & 6728,92 & 0,896 & $-0,875$ & 0,117 & 0,091 & 0,835 & $-1,004$ & 0,142 & $-0,49$ \\
\hline 14 & 6726,89 & 0,893 & $-0,874$ & 0,157 & 0,083 & 0,834 & $-1,006$ & 0,175 & ${ }^{-0,47}$ \\
\hline 15 & 6723,13 & 0,897 & $-0,908$ & 0,144 & 0,098 & 0,837 & $-1,038$ & 0,164 & $-0,49$ \\
\hline 16 & 6715,11 & 0,899 & $-0,938$ & 0,175 & 0,104 & 0,843 & $-1,071$ & 0,191 & $-0,483$ \\
\hline 17 & 6714,1 & 0,965 & $-0,992$ & 0,212 & 0,105 & 0,908 & $-1,12$ & 0,238 & $-0,452$ \\
\hline 18 & 6709,68 & 0,992 & $-1,025$ & 0,242 & 0,105 & 0,94 & $-1,154$ & 0,269 & $-0,435$ \\
\hline 19 & 6708,34 & 0,975 & $-1,018$ & 0,225 & 0,114 & 0,924 & $-1,156$ & 0,256 & $-0,45$ \\
\hline 20 & 6703,86 & 0,987 & $-1,012$ & 0,216 & 0,117 & 0,933 & $-1,156$ & 0,261 & $-0,441$ \\
\hline 21 & 6701,85 & 0,983 & $-1,018$ & 0,219 & 0,116 & 0,929 & $-1,156$ & 0,257 & $-0,444$ \\
\hline 22 & 6701,56 & 0,983 & $-1,018$ & 0,219 & 0,116 & 0,929 & $-1,156$ & 0,257 & $-0,444$ \\
\hline 23 & 6701,53 & 0,983 & $-1,018$ & 0,219 & 0,116 & 0,929 & $-1,156$ & 0,257 & $-0,445$ \\
\hline
\end{tabular}

Relative change in each estimate less than 0,0010

Tabel 4. Koefisien ARIMA $(4,1,3)$

\begin{tabular}{lrlrr}
\hline \multicolumn{1}{c}{ Type } & Coef SE & Coef & \multicolumn{1}{c}{ T } & \multicolumn{1}{c}{ P } \\
\hline AR1 & 0,9832 & 0,0592 & 16,61 & 0 \\
AR2 & $-1,0184$ & 0,0781 & $-13,04$ & 0 \\
AR3 & 0,2187 & 0,0881 & 2,48 & 0,014 \\
AR4 & 0,1161 & 0,0579 & 2 & 0,046 \\
MA1 & 0,929 & 0,0158 & 58,63 & 0 \\
MA2 & $-1,1559$ & 0,0001 & $-15887,1$ & 0 \\
MA3 & 0,2571 & 0,0218 & 11,78 & 0 \\
C & $-0,4446$ & 0,2404 & $-1,85$ & 0,065 \\
\hline
\end{tabular}

Differencing: 1 regular difference

Number of observations: Original series 329, after differencing 328

Residuals: $\quad$ SS $=6637,05$ (backforecasts excluded)

$$
M S=20,74 D F=320
$$

Tabel 5. Modified Box-Pierce (Ljung-Box) Chi-Square statistic

\begin{tabular}{lrrrr}
\hline Statistik & \multicolumn{4}{c}{ Nilai } \\
\hline Lag & 12 & 24 & 36 & 48 \\
Chi- & & & & \\
Square & 6 & 17,5 & 22,7 & 30,4 \\
DF & 4 & 16 & 28 & 40 \\
P-Value & 0,198 & 0,357 & 0,75 & 0,865 \\
\hline
\end{tabular}

Tabel 4 dan 5 menunjukkan hasil perhitungan dan hasil statistiks nilai koefisien Autoregressive (AR) dan Moving Average (MA). Seperti yang telah disebutkan bahwa persamaan model autoregressive order ke- $p$ dapat dituliskan sebagai berikut,

$\mathrm{y}_{\mathrm{t}}=\mathrm{c}+\phi_{1} \mathrm{y}_{\mathrm{t}-1}+\phi_{2} \mathrm{y}_{\mathrm{t}-2}+\ldots \ldots+\phi_{\mathrm{p}} \mathrm{y}_{\mathrm{t}-\mathrm{p}}+\varepsilon_{\mathrm{t}}$

Keterangan :

$\mathrm{y}_{\mathrm{t}}=$ nilai variable $\mathrm{y}$ pada tahun ke-t

$\phi=$ koefisien AR;AR(1), AR (2), AR (3), AR(4)

$\mathrm{c}=$ konstanta

$\varepsilon_{\mathrm{t}}=$ white noise atau residu.

Model Moving Average pada order ke- $q$ adalah sebagai berikut,

$\mathrm{y}_{\mathrm{t}}=\mathrm{c}+\varepsilon_{\mathrm{t}}+\Theta_{1} \varepsilon_{\mathrm{t}-1}+\Theta_{2} \varepsilon_{\mathrm{t}-2}+\ldots \ldots+\Theta_{\mathrm{q}} \varepsilon_{\mathrm{t}-\mathrm{q}}$

Keterangan:

$\mathrm{y}_{\mathrm{t}}=$ nilai variable $\mathrm{y}$ pada tahun ke-t.

$\Theta=$ koefisien $\mathrm{MA}=\mathrm{MA}(1), \operatorname{MA}(2), \operatorname{MA}(3)$

$\mathrm{c}=$ konstanta

$\varepsilon_{\mathrm{t}}=$ white noise pada tahun ke-t atau residu .

Persamaan menjadi :

$\mathrm{y}_{\mathrm{t}}{ }^{\prime}=\mathrm{c}+\phi_{1} \mathrm{y}_{\mathrm{t}-1}{ }+\ldots+\phi_{\mathrm{p}} \mathrm{y}_{\mathrm{t}-\mathrm{p}}+\Theta_{1 \varepsilon \mathrm{t}-1}+. .+\Theta_{\mathrm{q} \varepsilon \mathrm{t}-1}+\varepsilon_{\mathrm{t}} .$.

Model ARIMA(4,1,3) memenuhi enam kriteria dalam evaluasi model, yaitu:

a. Residual error bersifat random. Indikator yang digunakan adalah nilai $p$-value untuk uji statistik lebih besar dari 0,05. Pada Tabel 5 terlihat bahwa p-value lebih dari 0,05. Selain itu grafik ACF dan PACF dari residu menunjukkan pola cut off yang berarti sudah random, ditunjukkan oleh gambar 6 dan gambar 7 . 


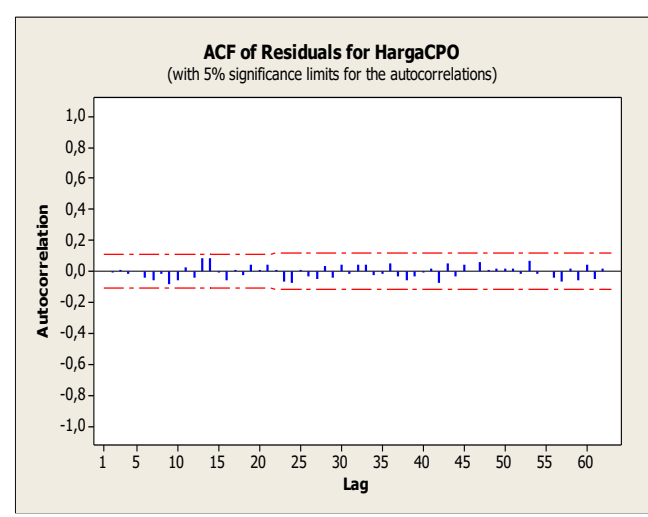

Gambar 6. ACF Residu Model ARIMA(4,1,3)

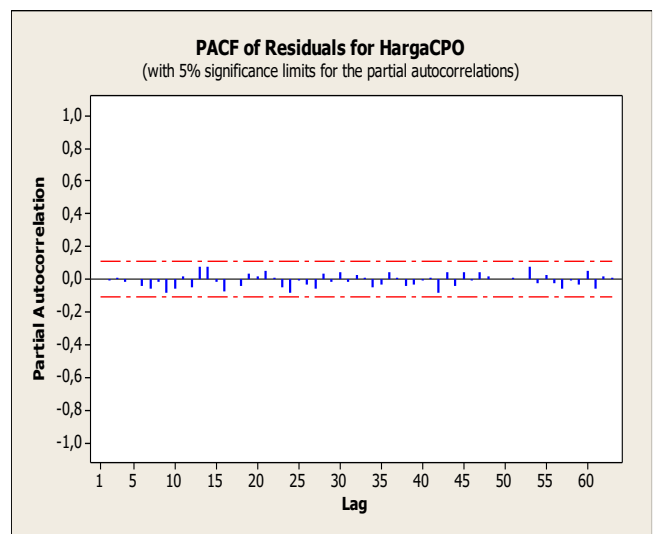

Gambar 7. PACF Residu Model ARIMA $(4,1,3)$

b. Model prosimonious. Model ARIMA $(4,1,3)$ merupakan model yang paling sederhana yang memungkinkan terpenuhinya persyaratan lain.

c. Parameter yang direstimasi berbeda nyata dengan nol. Hal ini ditunjukkan dengan p-value masing-masing koefisien AR dan MA yang kurang dari 0,05 pada Tabel 4

d. Kondisi invertibilitas ataupun stasioneritas terpenuhi. Hal ini ditunjukkan dengan jumlah koefisien MA dan AR yang masing -masing harus kurang dari 1 pada table 4 .

e. Proses iterasi convergence. Hal ini ditunjukkan pada saat analisis dijalankan akan terdapat katakata "relative change in each estimate less than 0,0010 ".

f. Model memiliki mean square of errors (MSE) yang kecil didapatkan MS $=20,74$, kecil untuk ukuran ARIMA.

Berdasar validitas tersebut di atas, maka model ARIMA $(4,1,3)$ dapat dikatakan valid untuk memodelkan harga CPO pada tahun 2018. Telah dilakukan forecast dan hasilnya terdapat pada gambar 8 dan Tabel 6, meliputi nilai forecast pada tingkat signifikansi $95 \%$, batas bawah dan batas atas.

Tabel 6 Nilai Peramalan (Forecast) Harga CPO, US\$

\begin{tabular}{rrrrc}
\multicolumn{5}{c}{ Hari- } \\
ke & Forecast & Bawah & \multicolumn{1}{c}{ Atas } & Tanggal \\
\hline 330 & 459,276 & 450,348 & 468,204 & $29 / 11 / 2018$ \\
331 & 461,023 & 448,05 & 473,996 & $30 / 11 / 2018$ \\
332 & 461,96 & 444,876 & 479,04 & $01 / 12 / 2018$ \\
333 & 461,66 & 440,809 & 482,511 & $02 / 12 / 2018$ \\
334 & 460,264 & 436,113 & 484,416 & $03 / 12 / 2018$ \\
335 & 459,16 & 432,197 & 486,124 & $04 / 12 / 2018$ \\
336 & 459,095 & 429,606 & 488,584 & $05 / 12 / 2018$ \\
337 & 459,371 & 427,442 & 491,299 & $06 / 12 / 2018$ \\
338 & 458,86 & 424,546 & 493,174 & $07 / 12 / 2018$ \\
339 & 457,49 & 420,952 & 494,029 & $08 / 12 / 2018$ \\
340 & 456,272 & 417,73 & 494,814 & $09 / 12 / 2018$ \\
341 & 455,945 & 415,548 & 496,341 & $10 / 12 / 2018$ \\
342 & 456,06 & 413,841 & 498,28 & $11 / 12 / 2018$ \\
343 & 455,637 & 411,595 & 499,679 & $12 / 12 / 2018$ \\
344 & 454,446 & 408,648 & 500,244 & $13 / 12 / 2018$ \\
345 & 453,248 & 405,821 & 500,676 & $14 / 12 / 2018$ \\
346 & 452,76 & 403,8 & 501,72 & $15 / 12 / 2018$ \\
347 & 452,746 & 402,275 & 503,217 & $16 / 12 / 2018$ \\
348 & 452,384 & 400,392 & 504,377 & $17 / 12 / 2018$ \\
349 & 451,353 & 397,869 & 504,837 & $18 / 12 / 2018$ \\
350 & 450,203 & 395,308 & 505,097 & $19 / 12 / 2018$ \\
351 & 449,597 & 393,365 & 505,83 & $20 / 12 / 2018$ \\
352 & 449,461 & 391,909 & 507,013 & $21 / 12 / 2018$ \\
353 & 449,128 & 390,246 & 508,009 & $22 / 12 / 2018$ \\
354 & 448,228 & 388,031 & 508,426 & $23 / 12 / 2018$ \\
355 & 447,139 & 385,68 & 508,598 & $24 / 12 / 2018$ \\
356 & 446,451 & 383,785 & 509,116 & $25 / 12 / 2018$ \\
357 & 446,203 & 382,352 & 510,055 & $26 / 12 / 2018$ \\
358 & 445,874 & 380,828 & 510,92 & $27 / 12 / 2018$ \\
359 & 445,081 & 378,846 & 511,316 & $28 / 12 / 2018$ \\
360 & 444,057 & 376,67 & 511,444 & $29 / 12 / 2018$ \\
361 & 443,314 & 374,819 & 511,809 & $30 / 12 / 2018$ \\
362 & 442,969 & 373,386 & 512,552 & $31 / 12 / 2018$ \\
363 & 442,626 & 371,951 & 513,302 & $01 / 01 / 2019$ \\
364 & 441,915 & 370,147 & 513,682 & $02 / 01 / 2019$ \\
365 & 440,958 & 368,125 & 513,791 & $03 / 01 / 2019$ \\
366 & 440,182 & 366,318 & 514,046 & $04 / 01 / 2019$ \\
367 & 439,754 & 364,878 & 514,63 & $05 / 01 / 2019$ \\
368 & 439,387 & 363,497 & 515,276 & $06 / 01 / 2019$ \\
369 & 438,736 & 361,833 & 515,64 & $07 / 01 / 2019$ \\
370 & 437,843 & 359,943 & 515,743 & $08 / 01 / 2019$ \\
371 & 437,052 & 358,184 & 515,92 & $09 / 01 / 2019$
\end{tabular}




\begin{tabular}{|c|c|c|c|c|c|c|c|c|c|}
\hline 372 & 36,555 & 356,737 & 516,373 & $10 / 01 / 2019$ & 418 & 407,417 & 291,653 & 523,182 & $25 / 02 / 2019$ \\
\hline 373 & 436,156 & 355,388 & 516,924 & 11/01/2019 & 419 & 406,828 & 290,406 & 523,249 & $26 / 02 / 2019$ \\
\hline 374 & 435,549 & 353,831 & 517,267 & $12 / 01 / 2019$ & 420 & 406,212 & 289,135 & 523,29 & $27 / 02 / 2019$ \\
\hline 375 & 434,713 & 352,057 & 517,37 & 13/01/2019 & 421 & 405,549 & 287,819 & 523,278 & $28 / 02 / 2019$ \\
\hline 376 & 433,92 & 350,348 & 517,493 & $14 / 01 / 2019$ & 422 & 404,877 & 286,5 & 523,253 & $01 / 03 / 2019$ \\
\hline 377 & 433,368 & 348,897 & 517,84 & 15/01/2019 & 423 & 404,244 & 285,225 & 523,264 & $02 / 03 / 2019$ \\
\hline 378 & 432,935 & 347,567 & 518,303 & $16 / 01 / 2019$ & 424 & 403,646 & 283,987 & 523,305 & 03/03/2019 \\
\hline 379 & 432,357 & 346,091 & 518,622 & $17 / 01 / 2019$ & 425 & 403,033 & 282,737 & 523,329 & $04 / 03 / 2019$ \\
\hline 380 & 431,572 & 344,417 & 518,726 & 18/01/2019 & 426 & 379 & 281,448 & 523,31 & 05/03/2019 \\
\hline 381 & 430,785 & 342,76 & 518,811 & 19/01/2019 & 427 & 401,711 & 280,15 & 523,272 & 06/03/2019 \\
\hline 382 & 430,191 & 341,31 & 519,072 & 20/01/2019 & 428 & 401,073 & 278,886 & 523,26 & 07/03/2019 \\
\hline 383 & 429,723 & 339,991 & 519,456 & 21/01/2019 & 429 & 400,466 & 277,656 & 523,276 & 08/03/2019 \\
\hline 384 & 429,162 & 338,577 & 519,747 & 22/01/2019 & 430 & 399,854 & 276,423 & 523,285 & 09/03/2019 \\
\hline 385 & 428,42 & 336,989 & 519,851 & 23/01/2019 & 431 & 399,207 & 275,158 & 523,257 & $10 / 03 / 2019$ \\
\hline 386 & 427,646 & 335,383 & 519,909 & 24/01/2019 & 432 & 398,544 & 273,88 & 523,209 & $11 / 03 / 2019$ \\
\hline 387 & 427,02 & 333,939 & 520,101 & 25/01/2019 & 433 & 397,902 & 272,627 & 523,177 & $12 / 03 / 2019$ \\
\hline 388 & 426,52 & 332,625 & 520,415 & 26/01/2019 & 434 & 397,289 & 271,406 & 523,171 & $13 / 03 / 2019$ \\
\hline 389 & 425,966 & 331,258 & & & & & & & \\
\hline 390 & 425,26 & 329,743 & 520,776 & 28/01/2019 & 436 & 396,035 & 268,943 & 523,126 & $15 / 03 / 2019$ \\
\hline 391 & 424,502 & 328,188 & 520,817 & 29/01/2019 & 437 & 76 & 267,685 & 523,068 & $16 / 03 / 2019$ \\
\hline 392 & 423,854 & 326,754 & 520,954 & $30 / 01 / 2019$ & 438 & 394,732 & 266,444 & 523,02 & $17 / 03 / 2019$ \\
\hline 393 & 423,324 & 325,444 & 521,204 & $31 / 01 / 2019$ & 439 & 394,112 & 265,23 & 522,994 & $18 / 03 / 2019$ \\
\hline 394 & 422,771 & 324,112 & 521,43 & 01/02/2019 & 440 & 393,497 & 264,024 & 522,97 & 19/03/2019 \\
\hline 395 & 422,093 & 322,658 & 521,528 & 02/02/2019 & 441 & 392,861 & 262,798 & 522,923 & $20 / 03 / 2019$ \\
\hline 396 & 421,354 & 321,152 & 521,556 & 03/02/2019 & 442 & 392,207 & 261,558 & 522,856 & $21 / 03 / 2019$ \\
\hline 397 & 420,69 & 319,732 & 521,649 & 04/02/2019 & 443 & 391,561 & 260,329 & 522,794 & $22 / 03 / 2019$ \\
\hline 398 & 420,134 & 318,425 & 521,843 & 05/02/2019 & 444 & & 124 & & $23 / 03 / 2019$ \\
\hline 399 & 419,578 & 317,119 & 522,036 & 06/02/2019 & 445 & 390,319 & 257,928 & 522,71 & $24 / 03 / 2019$ \\
\hline 400 & 418,922 & 315,717 & 522,127 & 07/02/2019 & 446 & 389,686 & 256,719 & 522,654 & $25 / 03 / 2019$ \\
\hline 401 & 418,2 & 314,256 & 522,144 & 08/02/2019 & 447 & 389,037 & 255,496 & 522,578 & 26/03/2019 \\
\hline 402 & 417,528 & 312,853 & 522,202 & 09/02/2019 & 448 & 388,391 & 254,279 & 522,503 & $27 / 03 / 2019$ \\
\hline 403 & 416,949 & 311,55 & 522,348 & $10 / 02 / 2019$ & 449 & 387,762 & 253,082 & 522,442 & $28 / 03 / 2019$ \\
\hline 404 & 416,386 & 310,265 & 522,508 & $11 / 02 / 2019$ & \multirow{14}{*}{\multicolumn{5}{|c|}{$\begin{array}{l}\text { Forecast telah dilakukan untuk } 120 \text { hari, } \\
\text { mulai hari ke- } 330 \text { atau } 29 \text { November } 2018 \text { (Tabel } \\
6 \text { dan Gambar } 8 \text { ). Model menunjukkan bahwa akan } \\
\text { terjadi kecenderungan penurunan harga CPO. } \\
\text { Hasil dari pemodelan dan forecast ini dapat } \\
\text { digunakan oleh industri dan sektor perdagangan } \\
\text { CPO untuk menyusun strategi dan mengantisipasi } \\
\text { dampak dari penurunan harga kelapa sawit. Model } \\
\text { dan hasil forecast juga dapat digunakan oleh pihak } \\
\text { pemerintah sebagai salah satu pertimbangan dalam } \\
\text { menyusun kebijakan berkaitan kelapa sawit. Penurunan } \\
\text { harga CPO dapat mempengaruhi keberlangsungan } \\
\text { industri CPO di Indonesia. }\end{array}$}} \\
\hline 405 & 415,747 & 308,906 & 522,589 & $12 / 02 / 2019$ & & & & & \\
\hline 406 & 415,043 & 307,486 & 522,599 & 13/02/2019 & & & & & \\
\hline 407 & 414,366 & 306,103 & 522,629 & $14 / 02 / 2019$ & & & & & \\
\hline 408 & 413,769 & 304,805 & 522,733 & $15 / 02 / 2019$ & & & & & \\
\hline 409 & 413,198 & 303,535 & 522,86 & $16 / 02 / 2019$ & & & & & \\
\hline 410 & 412,57 & 302,211 & 522,929 & $17 / 02 / 2019$ & & & & & \\
\hline 411 & 411,881 & 300,83 & 522,932 & $18 / 02 / 2019$ & & & & & \\
\hline 412 & 411,204 & 299,468 & 522,94 & $19 / 02 / 2019$ & & & & & \\
\hline 413 & 410,592 & 298,176 & 523,007 & 20/02/2019 & & & & & \\
\hline 414 & 410,011 & 296,919 & 523,104 & 21/02/2019 & & & & & \\
\hline 415 & 409,392 & 295,624 & 523,159 & $22 / 02 / 2019$ & & & & & \\
\hline 416 & 408,716 & 294,277 & 523,155 & 23/02/2019 & & & & & \\
\hline 417 & 408,041 & 292,937 & 523,145 & 24/02/2019 & & & & & \\
\hline
\end{tabular}




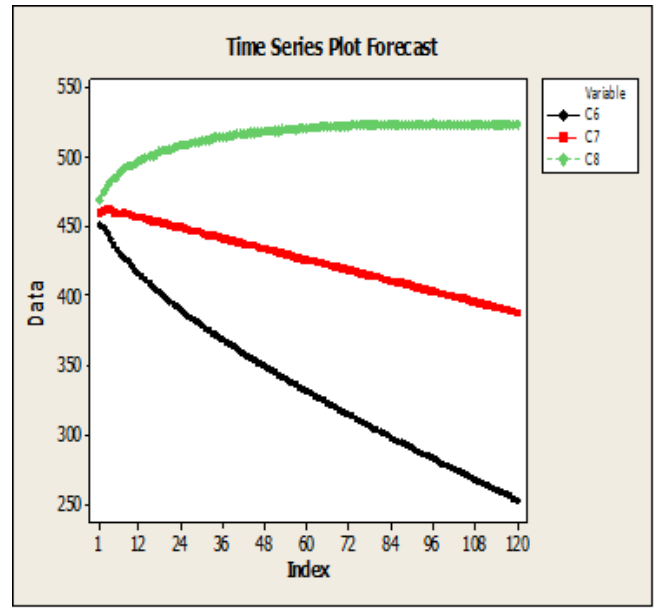

Gambar 8. Forecast Harga CPO Untuk 120 Hari

Pengolahan CPO menjadi produk yang memiliki nilai tambah yang dilakukan oleh industri dalam negri dapat mengurangi dampak dari penurunan harga CPO. Pada saat harga CPO turun, maka industri dalam negri yang menggunakan bahan dasar CPO mendapatkan manfaat berupa penurunan biaya bahan baku yang secara keseluruhan menurunkan biaya produksi dan biaya operasional.

\section{KESIMPULAN}

Model ARIMA $(4,1,3)$ valid untuk digunakan sebagai model harga CPO Indonesia pada tahun 2018. Hasil forecast untuk 120 hari yaitu mulai hari ke-329 menunjukkan adanya kecendarungan penurunan harga CPO.

\section{DAFTAR PUSTAKA}

Alatas, A. (2015). Trend Produksi dan Ekspor Minyak Sawit (CPO) Indonesia. Jurnal Agraris 1(2), 114 -124.

Badan Pusat Statistik, 2013, 2014, dan 2015. Diakses pada 1 Desember 2018 pukul 10.00 .

Bentivoglio, D., Finco, A, Bucci,G. (2018). International Journal of Energy Economics and Policy, 8(5), 49-57.

Buyung, Syechalad,N, Masbar,R., dan Nasir (2017), The Analysis of Factors Affecting CPO Export Price of Indonesia, European Journal of Accounting Auditing and Finance Research, 5(7), 17-29.

Firdaus,M. (2011), Aplikasi Ekonometrika Untuk Data Panel dan Time Series, PT Penerbit IPB Press Bogor.
GAPKI Indonesia Palm Oil Ascociation, https://gapki.id/ diakses pada 30 November 2018 pukul 8.00

Hyndman, R.J. dan Athanasopoulus,G. (2018), Forecasting: Principles and Practices, Monash University, Australia https://otexts.org/fpp2/ diakses pada 3 Desember 2018 pukul 8.00.

Kementerian Perdagangan, website: http://www.kemendag.go.id/id/economicprofile/10-main-and-potential-commodities http://www.kemendag.go.id/id/economicprofile/10-main-and-potentialcommodities. Diakses pada 1 Desember 2018 pukul 8.00 .

Kontan, website :

https://investasi.kontan.co.id/news/hargacpo-sulit-menanjak-pada-kuartal-ii-2018

Munadi, E. (2007). Penurunan Pajak Ekspor dan Dampaknya Terhadap Ekspor Minyak Kelapa Sawit Indonesia ke India (Pendekatan Error Correction Model). Informatika Pertanian 16(2), 1019-1035.

Nurcahyani,M., Masyhuri, Hartono,S., (2018). The Export Supply of Indonesian Crude Palm Oil (CPO) to India, Agro Ekonomi, 29 (1) , 18-31.

Rahim, N.F. (2018), A Comparative Review on Various Method of Forecasting Crude Palm Oil Prices, Journal of Physics: Conference Series, 1123, 012043.

Rambe, K.R. dan Kusnadi, N. (2018). Permintaan dan Penawaran Minyak Goreng Sawit Indonesia. Forum Agribisnis 8(1), 61-80. 